\title{
Aikuiskoulutuksen kokeilu- ja tutkimustoiminnan nykytila ja kehittämistarve ${ }_{1}$
}

\begin{abstract}
Huuhka, Kosti. 1982. Aikuiskoulutuksen kokeilu- ja tutkimustoiminnan nykytila ja kehittämistarve. Aikuiskasvatus 2, 1, 21-24. - Artikkeli on katsaus aikuiskoulutuksen kokeilu-ja suunnittelutoimintaan. Artikkelissa selvitetään aikuiskoulutuskomitean tutkimus- ja kokeilutoimintaan liittyviä esityksiä, jotka edelleenkin ovat ajankohtaisia. Komitea esitti aikuiskoulutuksen tutkimuspoliittisen kokonaisohjelman laatimista, tutkimuksen lähtökohtien ja painopistesuuntien määrittelemistä sekä tutkimuksen organisointia ja rahoitusta. Vuonna 1979 asetettu aikuiskoulutuksen va. kehittämisorganisaatio on yleissuunnitelmassaan sijoittanut aikuiskoulutuksen tutkimusta käsittelevän projektin alkavaksi toisessa vaiheessa, eli vuoden 1982 aikana. Kehittämistoiminnan ensimmäisen vaiheen projekteihin sisältyy kuitenkin monenlaista tutkimusta, kokeilua ja selvitystyötä.
\end{abstract}

\section{Kokeilu- ja tutkimus- toiminnan tarve}

Tarkoitukseni ei ole ryhtyä perustelemaan, miksi aikuiskoulutuksen kokeilu- ja tutkimustoimintaa tarvitaan. Mitä taas tulee kokeilu- ja tutkimustoiminnan nykytilaan ja kehittämistarpeeseen, en pyri käsittelemään sitä koko laajuudessa, vaan ainoastaan kehittämissuunnittelun näkökulmasta.

Palautan ensiksikin mieliin, mitä kokeilu- ja tutkimustoiminnasta on kehittämissuunnittelun yhteydessä aiemmin sanottu ja esitetty sekä mitä tästä on seurannut.

\section{Tutkimus osana aikuiskoulu- tuksen kehittämistä}

Vuosina 1971-75 työskennellyt aikuiskoulutuskomitea esitti II osamietinnössään, että aikuiskoulutuksen kehittämisen tulee rakentua luotettavalle tiedolle ja teoreettisille perusteille, mikä edellyttää tieteellistä tutkimusta. Tätä varten tuli laatia aikuiskoulutuksen tutkimuspoliittinen kokonaisohjelma, jonka perusteh-

1) Artikkeli on laadittu aikuiskoulutuksen johtoryhmän 21.12.81 järjestämän aikuiskoulutuksen kokeilu- ja tutkimustoimintaa käsitelleen seminaarin alustuksen pohjalta. tävät komitea jäsensi seuraaviksi:

- aikuiskasvatuksen aseman selvittäminen ja vahvistaminen tieteenalana ja itsenäisenä yliopistollisena oppiaineena;

- aikuiskasvatuksen tutkimustehtävien kartoittaminen ja tutkimuspoliittisen ohjelman niveltäminen omana alakokonaisuutena kasvatustieteiden ja muiden yhteiskuntatieteiden tutkimuspolitiikkaan;

- aikuiskasvatustutkimuksen painosuuntien määrääminen ja konkretisoiminen ajankohtaisiksi, kiireellisesti toteutettaviksi tutkimusohjelmiksi;

- tutkimusorganisaation suunnittelu ja kehittäminen yhteydessä aikuiskoulutuksen kokonaisjärjestelmään sekä

- suunnittelua ja tutkimusta palvelevan tilastollisen ja muun perustiedoston kehittäminen sekä alan tutkimuksen informaatiopalvelun organisoiminen.

Aikuiskoulutuskomitean mielestä sen tehtäviin ei tutkimuspolitiikan osalta kuulunut kuin yleisten suuntaviivojen alustava osoittaminen. Komitean mielestä sen sijaan oli tärkeää, että opetusministeriön aloitteesta laaditaan yksityiskohtainen aikuiskasvatuksen tutkimuspoliittinen ohjelma.

Komitean tarkoittamaa tutkimuspoliittista ohjelmaa ei vielä ole laadittu. Palaan myöhemmin komitean mietinnön aiheuttamiin toimenpiteisiin. Tässä yhteydessä totean, että nyt on 
tilaisuus tarkastella, missä määrin ja miltä osin komitean esittämät tutkimuspoliittisen ohjelman perustehtävät edellyttävät tarkistusta, jos tällaisen ohjelman laatimiseen nyt ryhdyttäisiin. Ja olisiko sellaiseen ehkä lainkaan tarvetta.

\section{Tutkimuksen tehtävät ja painotussuunnat}

Vaikka aikuiskoulutuskomitea osoittikin tutkimuspoliittisen ohjelman laatimisen opetusministeriön haltuun, se käsitteli kuitenkin verrattain laajasti tutkimustehtäviä ja painosuuntia, tutkimuksen organisaatiota sekä tutkimuksen rahoitusta.

Käsittelen lyhyehkösti näitä kahdesta syystä. Ensiksi sen vuoksi, että voidaan arvioida, missä määrin komitean mietinnön valmistumisen jälkeen harjoitettu tutkimustoiminta on seuraillut komitean esittämää suuntaa. Toiseksi sen vuoksi, että saataisiin evästystä siitä, miltä osin komitean ehdotukset ovat aikansa eläneitä.

\section{Perus- ja soveltava tutkimus}

Komitea jakoi aikuiskasvatuksen tutkimuksen monien muiden tutkimusalojen tapaan perustutkimukseen ja soveltavaan tutkimukseen. "Aikuiskasvatus on", sanoi komitea, "tieteenalana vielä siinä määrin kehittymätön, että tutkimuspolitiikassa on painotettava perustutkimuksen kehittämistä välttämättömänä ehtona soveltavankin tutkimuksen hyväksikäytölle. Perustutkimuksen ja soveltavan tutkimuksen välillä on aikuiskasvatuksessa vaikea osoittaa tarkkaa rajaa eikä jyrkkään erotteluun tule pyrkiäkään. Perustutkimuksella komitea tarkoittaa tutkimusta, joka ensisijasa palvelee teorian kehittämistä; soveltavaa on puolestaan tutkimus, joka saa tavoitteensa ja ongelmanasettelunsa ensisijaisesti käytännön koulutustoiminnan täsmentyneistä tarpeista."

Perustutkimuksen keskeiset tehtävät se ryhmitti seuraavasti:

- aikuiskasvatuksen käsitteen ja tavoitteiden empiiriselle ja filosofiselle tutkimukselle perustuva selvittäminen;

- yhteiskunnan aikuiskoulutustarpeiden analyysi;

- aikuisten koulutettavuuden tutkiminen;

- oppimistapahtuman tutkiminen;

- aikuiskoulutukseen osallistumisen perustutkimus;

- aikuiskouluttajan ammattikuvan selvittäminen sekä

- aikuiskoulutuksen organisaation, hallinnon ja talouden tutkiminen.
Edellä mainittuja voidaan jatkuvasti pitää aikuiskasvatustutkimuksen - aikuiskasvatus ymmärrettynä tässä yhteydessä nimenomaan tieteenalana - keskeisinä alueina. Sen sijaan voi esittää kysymyksen, missä määrin tällä tieteenalalla ylipäänsä on aiheellista ryhmittää tutkimustehtäviä perustutkimukseksi ja soveltavaksi tutkimukseksi. Komiteakin otti tähän jakoon varsin varovaisen kannan. Tämä ilmenee esim. siitä, että esittäessään mielestään tärkeimpiä ja kiireellisimmin toteutettavia tutkimustehtäviä, se ei enää sovella tämäntapaista jaoittelua. Kiireeilisinä tutkimustehtävinä se mainitsee seuraavia:

- yhteiskunnan aikuiskoulutustarpeiden selvittämisen suhteessa koulujärjestelmän antamaan yhtämittaiseen pohjakoulutukseen;

- vähiten pohjakoulutusta saaneiden ja vähiten aikuisopiskeluun osallistuvien osallistumisesteiden tutkimisen yhteiskunnallisen huono-osaisen kehäilmionä;

- aktiivisen rekrytoinnin mahdollisuuksien ja keinojen selvittämisen;

- opetusjärjestelyjen ja työtapojen didaktisen tutkimuksen, joka painottaa oppimisesteiden poistamista sekä

- aikuiskouluttajien ammattikuvatutkimuksen.

\section{Tutkimusorganisaatio ja tutkimuksen rahoitus}

Kuten muillakin tieteenaloilla, niin myös ajkuiskasvatuksessa tulee komitean mielestä noudattaa seuraavanlaisia periaatteita:

Tutkimus, alan korkeakouluopetus, suunnittelu ja aikuiskoulutustyö on nivellettävä mahdollisimman kiinteästi toisiinsa;

Resurssien tehokas käyttö edellyttää yhden riittävän suuren tutkimuskeskuksen kehittämistä. Samalla on kuitenkin edistettävä aikuiskasvatustutkimusta muissa korkeakouluissa sekä eriytyneissä tutkimusorganisaatioissa.

Tällaiseksi tutkimuskeskukseksi komitea esitti Tampereen yliopiston aikuiskasvatuksen laitosta, johon myös aikuiskasvattajien koulutus pääpainoisesti esitettiin keskitettäväksi. Alan tutkimus- ja koulutustoimintaa tuli laajentaa myös muihin korkeakouluihin ja Suomen Akatemian tieteellisistä tutkimusvaroista tuli osa käyttää aikuiskasvatustutkimukseen.

Mitä taas rahoitukseen tulee, yhteiskunnan taloudellinen tuki olisi ohjattava ennen muuta yksittäisten korkeakoulujen budjetteihin. Lisäksi tulisi opetusministeriöllä olla käytettävänä riittävä määräraha omia ja keskusvirastojen toimeksiantotutkimuksia varten. 
Kaikki edellä sanottu on toistaiseksi toteutunut vain vähäisessä määrin tai jäänyt tyystin toteutumatta. Esitetyn rahoitusjärjestelmän näkökulmasta tutkimustoiminta voidaan nähdä hieman toisin kuin perustutkimukseen ja soveltavaan tutkimukseen jakautuvana. Korkeakouluille niiden omien budjettien kautta ohjattavat tutkimusvarat tulisivat niiden omaharkintaiseen käyttöön tieteenalan ja sen teorian kehittämiseen. Aikuiskasvatus on käsittääkseni ns. käytännöllinen tieteenala, jonka kehittämisessä praktinen näkökohta on aina jollakin tavoin taustalla. Tämän vuoksi lienee hieman vaikeaa osoittaa jotakin tutkimusta pelkästään perustutkimukseksi.

Toimeksiantotutkimukset taas, joiden rahoittaminen esitetään opetusministeriön tehtäväksi, ovat joko suunnittelun tai käytännön ongelmien selvittämistä samaan tapaan kuin muussakin koulutustutkimuksessa.

\section{Kokeilutoiminta}

"Aikuiskoulutuksen järjestelmällisen kehittämisen toisiinsa liittyviä toimintoja ovat suunnittelu, tutkimus, kokeilu ja seuranta. Tutkimusta ja kokeilua voidaan pitää kehittämisjärjestelmässä suunnittelun välineinä. Kokeilu taas on tietyntyyppistä tutkimusta, jota harjoitetaan osana käytännön koulutustoimintaan", sanoi aikuisk oulutuskomitea.

Kehittämistoiminnan vastuun jakautuminen valtakunnalliselle, alueelliselle sekä paikalliselle ja organisaatiotasoille on toistaiseksi niin periaattellisesti kuin käytännön kannaltakin selvittämättä. Kuitenkin on selvää, että valtakunnallinen kehittämisvastuu niillä aikuiskoulutuksen aloilla, joille myös yhteiskunnan varoja suunnataan, kuuluu keskushallintoviranomaisille: opetusministeriölle ja keskushallitukselle.

Ainoa jollakin tapaa organisoitu kokeilutoiminnan muoto on opetusministeriön ja kouluhallituksen johdolla kansalais- ja työväenopistoissa harjoitettava kokeilu, johon myönnetään valtionapua budjetissa olevan määrärahan puitteissa. Tätä kokeilutoimintaa on harjoitettu vuodesta 1975 lähtien eli se on saatu aikaan jo ennen aikuiskoulutuskomitean mietinnön valmistumista. Sen lisäksi on eräitä yksittäisiä kokeiluprojekteja saatu aikaan yleissivistävän ja ammatillisen aikuiskoulutuksen sekä avoimen korkeakoulun toiminnan alalla.

Aikuiskoulutuskomitean mukaan ensimmäisinä tärkeysjärjestyksessä olivat seuraavat kokeilutehtävät:

- ammatillisen peruskoulutusohjelman opetusjärjestelyjen kokeilu ja seuranta;
- ohjatulle itseopiskelulle rakentuva monivälineopetuksen kokeilu sekä

- hakevan toiminnan kokeilu.

Tutkimuksen, kokeilun ja seurannan kannalta on välttämätöntä, että aikuiskoulutuksen organisaatioiden ja niiden toimintaa kuvailevien perustietojen kokoaminen ja järjestäminen jatkuvasti uusinnituiksi tiedostoiksi saadaan aikaan. Tätä koskeva aloite sisältyi myös aikuiskoulutuskomitean mietintöön.

\section{Tutkimus- ja kokeilutoiminta kehittämissuunnittelussa}

Aikuiskoulutuskomitean mietinnön valmistuttua opetusministeriö pyysi siitä lausuntoja eri tahoilta. Lausunnoista laaditun koonnan mukaan lausunnonantajat näyttävät kiinnittäneen erittäin vähän huomiota tutkimus- ja kokeilutoimintaan. Melkeinpä hämmästyttävänä voidaan pitää, että ne yliopistojen (3) kasvatustieteiden laitokset tai tiedekunnat, joilta lausuntoja pyydettiin; eivät näytä puuttuneen lainkaan kokeilu- ja tutkimustoimintaan. Tämä saattaa olla ymmärrettävissä myös niin, että ne täysin hyväksyivät komitean esitykset.

Muutoin kehittämissuunnittelussa tapahtui komitean mietinnön jälkeen lähes kolmen ja puolen vuoden keskeytys.

Vasta kesäkuussa 1978 valtioneuvosto teki jatkotoimenpiteiden edellyttämän päätöksensä aikuiskoulutuksen suunnittelu- ja kehittämisperiaatteista.

Päätöksen periaateosassa ei mainita mitään kokeilu- ja tutkimustoiminnasta. Sen sijaan toimenpideosan 8. kohdassa lausutaan: "Aikuiskoulutuksen kehittäminen perustetaan jatkuvalle kokeilu- ja tutkimustoiminnalle. Tieteen voimavaroja ohjataan nykyistä enemmän aikuiskoulutuksen alueelle. Alan perustiedoston kokoaminen ja analysointi järjestetään niin, että se palvelee koulutuksen suunnittelua."

\section{Väliaikainen kehittämis- organisaatio}

Periaatepäätöksen mukaista kehittämistoimintaa varten opetusministeriön avuksi asetettiin maaliskuussa 1979 väliaikainen kehittämisorganisaatio, johon kuuluu neuvottelukunta ja johtoryhmä.

Johtoryhmä sai ensimmäiseksi varsinaiseksi tehtäväkseen aikuiskoulutuksen kehittämisen yleissuunnitelman laatimisen. Tämä valmistui keväällä 1980. Suunnitelma käsittää lukuisia 
osatehtäviä - osaprojekteja - jotka ajallisesti jakautuvat I ja II vaiheen projekteihin. I vaiheen osaprojekteja on parhaillaan menossa kahdeksan. II vaiheen projektien aloittaminen ei ainakaan mainittavassa laajuudessa voi alkaa vielä vuoden 1982 aikana.

Mitä tulee aikuiskoulutuksen tutkimukseen, sitä koskeva kehittämisprojekti on tarkoitettu II vaiheen osaprojektiksi. Sen suunnittelu on ollut vasta alustavaa, pääpainon sisällön osalta ollessa aikuiskoulutuksen tutkimuksen organisoinnissa ja sen vaatimissa resursseissa sekä tutkimuksen painopistealueiden selvittämisessä.

\section{Selvitysprojektit ja selvitykset}

Voidaan tietysti kysyä, eikö tutkimusprojektia olisi tullut sijoittaa jo I vaiheen osaprojektiksi. Johtoryhmä katsoi kuitenkin aiheelliseksi - kun kaikkea ei ollut mahdollista esittää I vaiheeseen - sisällyttää siihen vain eräitä kehittämistyön kannalta perustavalaatuisia selvitysprojekteja. Tällaisia ovat ensiksikin aikuiskoulutuksen resurssien selvitys sekä selvitys kustannusten jaosta ja kustannusvastuusta. Selvitysluontoinen on myös peruskoulun ja lukion oppimäärien suoritusprojekti.

Merkittävin kehittämissuunnitteluun liittyvä selvitystyö on kuitenkin johtoryhmän yhdessä tilastokeskuksen kanssa suunnittelema ja tilastokeskuksen työvoimatutkimuksen yhteydessä toimeenpanema aikuiskoulutustutkimus. Tämä tutkimus on samantapainen, jollainen suoritettiin aikuiskoulutuskomitean toimeksiannosta 1970-luvun alussa. Sen odotetaan valmistuvan vuoden 1982 alkupuolella.
Edellä mainitun tutkimuksen kanssa rinnan työstettiin suunnitelma aikuiskoulutuksen tilaston uusimiseksi ja jatkuvaksi täydentämiseksi. Sen mukaan tilastointi kuuluu tilastokeskukselle ja suunnitelma toteutetaan asteittain useamman vuoden aikana. Suunnitelman toteuttaminen riippuu tilastokeskuksen resursseista. Myös kouluhallituksessa on vireillä eräiden aikuiskoulutustiedostojen kehittäminen.

\section{Tutkimus, kokeilu ja selvitystyö projektikohtaista}

Muutoin johtoryhmä on edellyttänyt, että tutkimus, kokeilu ja selvitystyö kehittämistoiminnan tässä vaiheessa on projektikohtaista. Kunkin projektin - sitä varten asetetun toimikunnan tai työryhmän - tulee harkita, millaista tutkimusta, kokeilua tai selvitystyötä sen tehtävä edellyttää.

Esimerkkinä mainitsen kansanopistoprojektin. Kansanopistotoimikunta suoritutti työnsä ensimmäisessä vaiheessa selvityksen kansanopiston opiskelijain koulutus- ja uravalinnoista. Se suoritettiin keväällä 1980 sekä siihen liittyvä seurantatutkimus vuotta myöhemmin. Nämä ovat antaneet varsin hyödyllistä tietoa toimikunnalle.

Edelleen kansanopistotoimikunta on päättänyt esittää toimeenpantavaksi tutkimuksen sisäoppilaitosmuotoisen oppilaitoksen kasvatuksellisesta merkityksestä.

Mitä kokeilutoimintaan tulee, osaprojektien yhteydessä tuskin voidaan kovin merkittävää suunnitteluun liittyvää kokeilutoimintaa panna vireille sen vaatiman keston vuoksi. 